\title{
12 Months Retention in Care and Viral Suppression amongst HIV Infected Women (HIVIW) on Option B+ in Yaoundé
}

\author{
Anne Esther Njom Nlend ${ }^{1,2 *}$, Sonia Mahop Ma Lappe ${ }^{2}$, Arsene Brunelle Sandie ${ }^{3}$ \\ ${ }^{1}$ Essos Hospital Centre, National Insurance Fund, Yaoundé, Cameroon; \\ ${ }^{2}$ Higher Institute of Medical Technology Nkolondom, Department of Clinical Sciences, University of Douala, \\ Cameroon; Yaoundé, Cameroon \\ ${ }^{3}$ Ministry of Economy planning and development and economy, Statistics and Demography Unit ,Yaoundé,
} Cameroon

*Corresponding Author: Anne Esther Njom Nlend, Associate Professor of Pediatrics; Director, Essos Hospital Centre, National Insurance Fund, Yaoundé, Cameroon, Email: anne.njom@gmail.com

\begin{abstract}
Background: Retention in care of HIVIW after delivery remains a key challenge in routine life settings; in addition, few studies have reported on post partum viral suppression of HIVIW at the era of test and treat.
\end{abstract}

Objective: Our objective was to assess the retention in care at 12-months postpartum and viral suppression amongst HIVIW on option B+ at Essos Hospital Centre.

Method: We conducted a cross sectional analytic study over a 6 month-period from January to June 2019. HIVIW on option B+, having delivered at least 12 months prior to the onset of the study were included and surveyed using a semi-structured questionnaire. Primary end-points were 1/ 12-month retention 2/ adherence to follow-up defined by at least one quarterly postpartum visit and 3/ viral suppression defined by a viral load <40 copies/ml at the last control.Factors associated with adherence to follow-up(FU) and viral suppression were assessed in uni and multivariate analysis using Software $R$ version 3.6; with $p<0.05$ considered statistically significant.

Results: We included 106 women with a median age of 35 years [IQR=31-38]. Almost 2 of 3 (67,92\%) were living as a couple, with a serodiscordant HIV negative partner for half of them (54\%).Most of the women $(57,55 \%)$ had reached the secondary level of education while 44,34\% were working in the informal sector and $41,55 \%$ had no regular income. Rates of retention, adherence to follow-up and viral suppression were respectfully measured at $65 \%, 82.08 \%$ and $93.55 \%$. A post-partum viral load measurement was mostly due to non-adherence to $F U(p=0.00)$. In multivariate analysis, monthly income $(p=0.04)$ and lack of viral load measure $(p=0.0033)$ influenced retention in follow-up.

Conclusion: Most HIVIW in retention and adherent to 12-month post-partum follow-up had an undetectable viral load in this setting. Monthly income and missing measurements of viral load were associated with low adherence to follow-up.

\section{INTRODUCTION}

The HIV pandemic continues to affect the world globally as a matter of public health with almost 37.9 million people living with HIV in 2018, and significant decline of AIDS-related deaths $[1,2]$. Regional disparities contribute to making Africa one of the hotspots of the pandemic worldwide with more than 25.6 million people infected, mostly female. In Cameroon, the prevalence rate amongst women was higher, with a twofold $(5,6 \%)$ difference amongst women than men of adult age $(2,9 \%)$ in the early 2010s [3]. Option B+ was introduced nationwide in 2012 in order to accelerate the elimination of transmission of HIV from mother-to-child and keep them alive [4].

Thus antiretroviral therapy is started as early as possible during or prior to pregnancy irrespective of clinical, immunological and/or viral status and aims at being continued for life [4]. Despite evidence of success of this strategy in reducing MTCT of HIV documented in Yaoundé [5], many worries have been raised about the difficulties of follow up of HIV 
positive women after delivery. Some among them claim that they just wanted a child and didn't feel sick [6]. This attitude has resulted in critical shortages in follow-up after delivery and even in treatment interruption during lactation with harmful consequences for both mother and child $[7,8]$. The operational response to these post-partum bottlenecks have included, among others, the involvement of partners, use of different mobile technologies, mentorship using mothers and expert patients, and the implementation of adherence counseling groups for mothers started on ARVs during or after pregnancy $[8,9]$. In Yaoundé, some of these strategies have been documented earlier especially regarding breastfeeding support groups, notably prior the $\mathrm{B}+$ period [10]. In this context, while attempting to develop a more comprehensive response to the retention in care of positive pregnant women in the era of $\mathrm{B}+$ and universal antiretroviral treatment, we designed this study in order to assess 1/ the 12-month retention rate, $2 /$ factors influencing adherence to follow-up and 3/ viral suppression among mothers retained in care

\section{METHOD}

\subsection{Study Setting}

This was a cross sectional analytic study targeting HIV infected women 12 months after delivery, and followed up at Essos Hospital Centre(EHC).EHC is a referral PMTCT center operating since the early 2000s, in Yaoundé; the characteristics of this centre were extensively described elsewhere [10]. HIV infected pregnant women on Option $\mathrm{B}+$ were enrolled from January to December 2017. Files of HIV positive women identified, with a delivery date between January to December 2017 were extracted from the maternity registry and merged with the National code of HIV patients' unique identifier at this HIV treatment center. All patientsmeeting the inclusion criteria were contacted by phone for a short interview to explain the study, register consent and apply a short questionnaire for data collection. The

Table1. Sociodemographic characteristic of women on Option B+ at !2 months post-partum

\begin{tabular}{|c|c|c|c|}
\hline & & Number & Frequency $(\%)$ \\
\hline \multicolumn{4}{|c|}{ Matrimonial status } \\
\hline & Single & 8 & 7.55 \\
\hline & Married & 26 & 24.53 \\
\hline & In couple & 72 & 67.92 \\
\hline \multicolumn{4}{|c|}{ Education } \\
\hline- & Primary & 21 & 19.81 \\
\hline- & Secondary & 61 & 57.55 \\
\hline & Higher education & 24 & 22.64 \\
\hline
\end{tabular}

following data were collected: sociodemographic, clinical, obstetrical and particularly post-natal follow up after delivery; number of post-natal quarterly visits, measurement of viral load post-partum. Retention was measured using both registers of antenatal consultation and PMTCT. Adherence to follow up was evaluated quarterly by the community worker in charge of patient follow up and by the dispenser of ARVs at the pharmacy.

\subsection{Statistical Analysis}

Data entry was done using CsPro software, version 7.2. All statistical analyses were performed with $\mathrm{R}$ software, version 3.6.0. The Chi-square test was used for the independence test, the Fisher exact test was used alternately when the assumptions for the Chi-square test were not satisfied. The logistic regression model was used to estimate the Odds Ratio (OR) and their $95 \%$ confidence intervals.

\section{ReSUlts}

In total among 200 pregnant women in 2017, 130 were kept in follow-up at 12 months postpartum giving a retention rate of $65 \%$. However, due do missing data among those 130, only 106 were finally included for in-depth study of associated factors of adherence during the 12 months of post-partum. Figure one provides an overview of the flow chart of patient enrolment.

\subsection{Sociodemographic and Characteristics of the Population}

The median age of women included stood at 35 years, interquartile range [31-38]. Mothers were mostly living as a couple $(67.92 \%), 57.55 \%$ of them had a secondary level of education. It's to be noted that the majority were working in the informal sector $(44.34 \%)$ or had no regular income. Partners were seroconcordant positive in $34.3 \%$ (table 1). In addition, all those women were classified in WHO clinical stage 1 or 2, given Cotrimoxazole and received the standard first line recommended ART for pregnant women, free of protease inhibitors. 
12 Months Retention in Care and Viral Suppression amongst HIV Infected Women (HIVIW) on Option B+ in Yaoundé

\begin{tabular}{|c|c|c|}
\hline \multicolumn{3}{|l|}{ Employment } \\
\hline - $\quad$ White coolar & 7 & 6.6 \\
\hline Worker in private & 4 & 3.77 \\
\hline Jobless & 35 & 33.02 \\
\hline Student & 6 & 5.66 \\
\hline home worker & 7 & 6.6 \\
\hline Informal sector & 47 & 44.34 \\
\hline \multicolumn{3}{|l|}{ Income } \\
\hline $\begin{array}{ll} & \text { Below minimal } \\
\end{array}$ & 23 & 21.70 \\
\hline Above minimal & 39 & 36.79 \\
\hline No income & 44 & 41.51 \\
\hline \multicolumn{3}{|l|}{ HIV status of the partner } \\
\hline$-\quad$ Seropositive & 35 & 34.31 \\
\hline Seronegative & 55 & 53.92 \\
\hline Unknown & 12 & 11.76 \\
\hline \multicolumn{3}{|l|}{ Age } \\
\hline $25-30$ & 23 & 21.7 \\
\hline $30-35$ & 32 & 30.19 \\
\hline $35-40$ & 39 & 36.79 \\
\hline $40-45$ & 12 & 11.32 \\
\hline $\begin{array}{l}\text { 3.2. Viral Load Measurement and } \\
\text { Undetectability at } 12 \text { Months Post Partum } \\
\text { In this population, the provision of ART } \\
\text { monthly or quarterly was not different among } \\
\text { the women adherent and those non adherent. } \\
\text { Similarly the rate of women with undetectable } \\
\text { viral load was comparable among those } 2 \\
\text { groups. However the proportion of women } \\
\text { having done a viral load measurement at } 12 \\
\text { months post-partum was better in those adherent } \\
\text { to follow up than their counterparts Among the }\end{array}$ & $\begin{array}{l}\text { vira } \\
84 / 8 \\
\text { post } \\
\text { reco } \\
\text { mea } \\
\text { und } \\
\text { freq } \\
\text { (93. } \\
\text { diffe } \\
\text { on t } \\
\text { Tab. }\end{array}$ & $\begin{array}{l}\text { ment during pregnancy and } \\
\text { undetectable. At } 12 \text { months } \\
\text { viral load measurement was } \\
106(59 \%) \text { had a viral } \\
\text { d } 62 / 63 \quad(98 \%) \text { were } \\
\text { load measurement was more } \\
\text { adherent to follow-up } \\
5 \% \quad(p=0.0) \text { however no } \\
\text { suppression was found based } \\
\text { f post-partum follow up. (See }\end{array}$ \\
\hline
\end{tabular}

106 post-partum women, 85/106(80\%) did a

Table2. Distribution of women on Option B+at!2 months post partum according adherence to quarterly follow up and viral suppression

\begin{tabular}{|l|l|l|l|}
\hline Variable & $\begin{array}{l}\text { Adherent Quarterly FU } \\
(\mathbf{N = 8 7 , 8 2 , 0 8 \%})\end{array}$ & $\begin{array}{l}\text { Non Adherent to quarterly } \\
\text { FU (N=19, 17, 92\%) }\end{array}$ & $\begin{array}{c}\text { p- } \\
\text { value }\end{array}$ \\
\hline $\begin{array}{l}\text { Viral load measurement at 12 months } \\
\text { post partum }\end{array}$ & & & 0 \\
\hline Yes & $59(93,65)$ & $4(6,35)$ & \\
\hline No & $28(65,12)$ & $15(34,88)$ & \\
\hline Undetectable viral load (N=63) & & & 0,79 \\
\hline Yes & $58(93,55)$ & $4(6,45)$ & \\
\hline No & $1(100)$ & $0(0)$ & \\
\hline
\end{tabular}

\subsection{Factors Associated with Quarterly} Follow-Up at 12 Months Post-Partum.

Inthis population, in adjusted analysis, women with consistent quarterly follow-up were more

Table3. Factors associated to adherence to follow up at 12 months post partum: unadjusted and adjusted analysis

\begin{tabular}{|l|l|l|l|l|}
\hline & OR(95\%CI) unadjusted & p.value & OR (95\% CI) adjusted & p.value \\
\hline Income & & & & \\
\hline Lower than minimum & Ref & & Ref & \\
\hline Above minimum & $0.36(0.07-1.71)$ & 0.19 & $0.18(0.02-1.49)$ & 0.11 \\
\hline No income & $0.23(0.05-1.07)$ & 0.06 & $0.11(0.01-0.87)$ & 0.04 \\
\hline $\begin{array}{l}\text { Viral load measurement at } \\
\text { months post partum }\end{array}$ & & & & \\
\hline Yes & Ref & & Ref & \\
\hline No & $0.15(0.05-0.44)$ & 0.0007 & $0.17(0.05-0.55)$ & 0.0033 \\
\hline
\end{tabular}


12 Months Retention in Care and Viral Suppression amongst HIV Infected Women (HIVIW) on Option B+ in Yaoundé

\begin{tabular}{|l|l|l|l|l|}
\hline Support group & & & & \\
\hline \multicolumn{1}{|c|}{ Yes } & Ref & & Ref & \\
\hline No measurement during & $0.45(0.1-1.20)$ & 0.11 & $0.49(0.16-1.53)$ & 0.22 \\
\hline $\begin{array}{l}\text { Viral } \\
\text { pregnancy }\end{array}$ & & & & \\
\hline Yes & Réf. & & Réf. & \\
\hline No & $0.68(0.25-1.84)$ & 0.44 & $0.58(0.18-1.89)$ & 0.37 \\
\hline HIV status of the partner & & & & \\
\hline Positive & Réf. & & Réf. & \\
\hline Négative & $1.07(0.37-3.10)$ & 0.89 & $0.70(0.20-2.40)$ & 0.57 \\
\hline Unknown & $0.67(0.16-2.83)$ & 0.58 & $0.57(0.12-2.76)$ & 0.48 \\
\hline
\end{tabular}

OR: odds ratio ; CI: Confidence Interval

\section{DISCUSSION}

The main findings of this study are a retention rate of $65 \%$ at 12 months post-partum, full compliance to quarterly follow up of $80 \%$ and a viral suppression above $90 \%$ among those retained; however, it should be noted that the coverage of viral load measurement was far from meeting the third 90s target either during pregnancy or after delivery.

Besides these shortages, our first comment acknowledges that our lost to follow-up of 35\% at 12 months was quite lower than the $53.7 \%$ recorded in GOMBA [11], though parallel to data of 14 months retention post-delivery in Uganda [12]. In addition, our rate of retention stands within the interval recorded in various settings of sub-Saharan Africa [13]. Overall, the retention rate of $65 \%$ in this setting shifts between the $76 \%$ recorded in Douala and the $64 \%$ recorded in Kumbain the same country [14, 15].Besides retention, adherence to follow-up in this setting was quite promising; of note a laudable rate of $82 \%$ of women were compliant to quarterly follow-up compared to data reported by Mellinset al in similar settings [16]. We can assume that the older age (median age of 35 years) of our mothers may have motivated them to be more respectful of the various appointments at the clinic. In fact, the influence of maternal age on adherence to post-natal visits was earlier outlined by other teams assuming a longer past story of PMTCT [14, 17]. However, in our setting an association between age and adherence was not formally identified. Regarding viral suppression, we can appreciate the high rate of viral suppression but this should not lead us to ignore the middle coverage of viral load measurement at 12 months postpartum as mentioned above. Regardless of this weakness, our rate of $93.5 \%$ of viral suppression is reassuring and above the $77 \%$ rate posted from Uganda within the same timeframe [18]. In addition, our suppression rate is comparable to the one observed in the Pure study under research-related conditions. On the contrary, data from the field shows a very low rate of viral load testing both during pregnancy and after in Zimbabwe, making our achievement appreciable $[19,20]$. In this setting, women likely to have completed post-partum follow up had a regular monthly income and post-natal measurement of viral load. Our findings therefore corroborate reports of Hoffmann where cost and time to go to health facilities negatively affected adherence to post-natal routine care [17]. On the other hand, lack of a viral load which can be attributed to both financial causes and or denial attitudes, was correlated with lower adherence to FU. These latest findings are concordant with allissues raised beyond $\mathrm{B}+$; with the need to increase the rate of fully engagement to antiretroviral treatment and services among women retained in careafter delivery and for lifelong time [21].

\section{CONClusion}

In this setting, the retention rate stood at $65 \%$ but conversely compliance to follow-up was high including viral suppression at 12 months post-partum. These laudable results should be strengthened while increasing the rate of retention for all mothers.

\section{ACKNOWLEDGMENT}

We are grateful to mothers for providing their consent and to the medical staff for their support indata collection for this study.

\section{REFERENCES}

[1] Global HIV \& AIDS statistics - 2019 fact sheethttps://www.unaids.org/en/resources/fact sheet/2019/ 2019-UNAIDS-data assessed 6/6/ 2020

[2] UNAIDS Data 2019,https://www.unaids.org/en/ resources/documents/2019/2019-UNAIDS-data assessed 6/6/2020

[3] ICF International, Ministry of Economy, Planning and Regional Development (Cameroon), Ministry of Public Health 
(Cameroon), National Institute of Statistics (Cameroon), Pasteur Center of Cameroon. Cameroon Demographic and Health Survey 2011. Fairfax, United States of America: ICF International. Eliminating PTMCT

[4] Vrazo AC, Sullivan D, Ryan Phelps B. Eliminating Mother-to-Child Transmission of HIV by 2030: 5 Strategies to Ensure Continued Progress. GlobHealthSciPract. 2018 Jun 29;6(2):249-256.

[5] Njom AN, Nguedou KM, Koki PN, et al. 12months efficacy of option $\mathrm{B}+$ for prevention of mother-to-child transmission of HIV in Yaoundé, Cameroon. Revue d'epidemiologieet de santepublique. 2019 May; 67(3):163-7.

[6] Ddaaki, W., Church, K., Zaba, B., \&al. (2017). 'I wanted to safeguard the baby': a qualitative study to understand the experiences of Option $\mathrm{B}+$ for pregnant women and the potential implications for 'test-and-treat' in four subSaharan African settings. Sexuallytransmitted infections, 93(Suppl 3), e052972.

[7] Tenthani L, Haas AD, Tweya H, et al. Retention in care under universal antiretroviral therapy for HIV-infected pregnant and breastfeeding women ('Option B+') in Malawi: AIDS. févr 2014;28(4):589-98.

[8] Foster G, Orne-Gliemann J, Font H, et al. Impact of Facility-Based Mother Support Groups on Retention in Care and PMTCT Outcomes in Rural Zimbabwe: The EPAZ Cluster-Randomized Controlled Trial. JAIDS J Acquir Immune DeficSyndr. juin 2017;75: S207-15.

[9] Wesevich A, Mtande T, Saidi F, et al. Role of male partner involvement in ART retention and adherence in Malawi's Option B+ program. AIDS Care. 2017Nov; 29(11):1417-1425.

[10] NjomNlend AE, Same Ekobo C, BagfegueEkani $\mathrm{B}$, et al. Preventing HIV-1 transmission in breastfed infants in low resource settings: early HIV infection and late postnatal transmission in a routine prevention of mother-to-child transmission program in Yaounde, Cameroon. Journal of tropical pediatrics. 2013 Oct 1;59 (5):387-92

[11] Kiwanuka, G., Kiwanuka, N., Muneza, Fet al (2018). Retention of HIV infected pregnant and breastfeeding women on option $\mathrm{B}+$ in Gomba District, Uganda: a retrospective cohort study. BMC infectiousdiseases, 18(1), 533.

[12] Decker S, Rempis E, Schnack A, et al. Prevention of mother-to-child transmission of
HIV:Postpartum adherence to Option B+ until 18 months in Western Uganda. PLoS One.2017 Jun 29; 12(6):e0179448.

[13] Knettel BA, Cichowitz C, Ngocho JS, et al. Retention in HIV Care During Pregnancy and the Postpartum Period in the Option B+ Era: Systematic Review and Meta-Analysis of Studies in Africa. J Acquir Immune DeficSyndr. 2018 Apr 15; 77(5):427-438.

[14] Calixte I. Penda, Joseph Fokam, Serge C. Billong, et al. Determinants of Retention on the Prevention of Mother-to-Child HIV Transmission (Option B+) in Cameroon. 2019 March 29; 1(4):1-8

[15] Atanga PN, Ndetan HT, Achidi EA, et al. Retention in care and reasons for discontinuation of lifelong antiretroviral therapy in a cohort of Cameroonian pregnant and breastfeeding HIV-positive women initiating 'Option B+' in the South West Region. Trop Med Int Health. févr 2017; 22(2): 161-70.

[16] Mellins CA, Chu C, Malee K, et al. Adherence to antiretroviral treatment among pregnant and postpartum HIV-infected women. AIDS Care. 1 sept 2008; 20(8):958-68.

[17] Hoffman RM, Phiri K, Parent J, et al. Factors associated with retention in Option $\mathrm{B}+$ in Malawi: a case control study. J Int AIDS Soc. 2017; 20(1):21464.

[18] Mugavero MJ, Westfall AO, Zinski A, et al. Measuring Retention in HIV Care: The Elusive Gold Standard. J Acquir Immune DeficSyndr 1999. 15 déc 2012; 61(5):574-80.

[19] Hosseinipour M, Nelson JAE, Trapence C, et al. Viral Suppression and HIV Drug Resistance at 6 Months Among Women in Malawi's Option B+ Program: Results From the PURE Malawi Study. J Acquir Immune DeficSyndr. 2017;75 Suppl 2(Suppl 2):S149-S155.

[20] Nyakura J, Shewade HD, Ade S, et al. Viral load testing among women on 'option $\mathrm{B}+$ ' in Mazowe, Zimbabwe: How well are we doing?. PLoS One. 2019;14(12):e0225476. Published 2019 Dec 3.

[21] Myer L, Phillips TK. Beyond "option B+": understanding antiretroviral therapy (ART) adherence, retention in care and engagement in ART Services among pregnant and postpartum women initiating therapy in sub-Saharan Africa. JAIDS Journal of Acquired Immune Deficiency Syndromes. 2017 Jun 1;75:S115-2

Citation: Anne Esther NjomNlend, SoniaMahop Ma Lappe, Arsene Brunelle Sandie, 12 Months Retention in Care and Viral Suppression amongst HIV Infected Women (HIVIW) on Option B+ in Yaoundé. ARC Journal of Public Health and Community Medicine. 2020; 5(3) 39-43.DOI: doi.org/10.20431/2456-0596.0503005.

Copyright: (C) 2020 Authors. This is an open-access article distributed under the terms of the Creative Commons Attribution License, which permits unrestricted use, distribution, and reproduction in any medium, provided the original author and source are credited. 